\title{
Strategic Planning of Information System in PT Satya Mitra Sejahtera Using Ward and Peppard
}

\author{
Reza Farid Azizi \\ Information System, Kristen Satya Wacana University, \\ Salatiga, 50715, Indonesia \\ 682016101@student.uksw.edu
}

\author{
Melkior N. N. Sitokdana \\ Information System, Kristen Satya Wacana University, \\ Salatiga, 50715, Indonesia \\ melkior.sitokdana@uksw.edu
}

\begin{abstract}
Increasing demand in every company for information systems strategic planning in order to increase efficiency, effectiveness and increase competitive advantage programmatically with a priority scale, given the information system resources and other supporting devices are still limited, so the existence of an information system strategic plan will help the company. One of them is PT Satya Mitra Sejahtera, which is engaged in business, which is currently not fully using information systems to its full potential. The quality of information systems becomes the most important component because it requires an analysis of the strategic planning of information systems to determine whether the information system that was developed can be used properly. In this study, the author will conduct an information system strategic planning using the Ward and Peppard method. This method was chosen because it can evaluate business conditions and information systems that occur at this time, by looking at the business environment and information system environment externally and internally. The Ward and Peppard method have several stages, the first stage of analyzing the internal and external business environment using the PEST and value chain. Analysis of the internal and external environment of information systems using SWOT, while the application portfolio mapping uses Mc Farlan Strategic Grid. The results of strategic design research using Ward and Peppard methods can produce maps of internal and external conditions of the organization, so that can find out the strengths, weaknesses, opportunities, and threats owned by PT. Satya Mitra Sejahtera.
\end{abstract}

Keywords - Strategic Planning, Information System, Ward and Peppard, Mc Farlan Strategic Grid, PEST, Value chain.

\section{INTRODUCTION}

Information system planning in an organization is very important to improve efficiency, effectiveness, and increase competitive advantage. One of the failure factors in an organization is an unsupported information system. Due to the information system and information technology that will continue to develop, an organization really needs strategic planning information system. according to kerzner strategic planning is a management tool used to manage current conditions for projecting conditions in the future, so the strategic plan is a guide that organizations can use from current conditions for those working towards 5 to 10 years to front. Strategic can be defined as a series of actions taken as an instrument to increase the success and long-term strength of a company in achieving a competitive advantage. Where strategic planning provides a way to achieve organizational goals and objectives to the fullest. One of the organizations that need to have an information system strategic plan is PT Satya Mitra Sejahtera.

PT Satya Mitra Sejahtera has not fully used the information system to its full potential. The quality of the information system becomes the most important component because it requires an analysis of the strategic planning of the information system to find out whether the developed information system can be used properly. PT Satya Mitra Sejahtera was established by YPTKSW as an effort to realize the independence of the institution. PT Satya Mitra Sejahtera is engaged in the business sector, the business units that are managed are: the "SUBSIDARI" business unit ("SWCU" guest house, shady cafe, car rental, employee loan, and savings unit, souvenir center and uni store), and the Rental System Business Unit (cafeteria central, IKASATYA Foto Copy and Tower Sign).

In carrying out the organizational process which is engaged in business, PT Satya Mitra Sejahtera has several problems, namely, the lack of information sources on the existence of the business sector and the recruitment of workers at PT Satya Mitra Sejahtera. The unavailability of information system application that can facilitate business management. In addition, the lack of information systems results in the community not knowing enough information about business and the recruitment of existing workers. Therefore, PT Satya Mitra Sejahtera requires information system to improve the quality of public services that can be accessed easily, obtain data, and information that is precise, and accurate. based on the above problems, then the research was carried out to make strategic planning for information system.

In this research, the author will carry out a strategic planning information system using the Ward and Peppard method. This method was chosen because it can evaluate business conditions and the current information system, by looking at the business environment and the information system environment externally and 
internally. The Ward and Peppard method have several stages, the first stage of analyzing the internal and external business environment using the PEST and Value chain. Internal and external environment analysis information system using SWOT, while the application portfolio mapping using Mc Farlan Strategic Grid.

The purpose of this research will result in a strategic information system planning so that PT. Satya Mitra Sejahtera can invest in an information system programmatically on a priority scale, bearing in mind the resources of the information system and other supporting devices are still limited, so the existence of an information system strategic plan will help the organization.

Research on the strategic planning of information systems is not a new thing, then some relevant research used as a reference in this research, are as follows;

Research on Strategic Planning of Information Systems Using the Ward and Peppard Method at PT. Serasi Autoraya. In the research, said Information Systems Strategic Planning produced a recommendation to be developed among Trac Website Development, SAP application development, customer service information system application development, asset information system applications, and Executive Information System Development. With the hope to provide clarity of direction and encourage companies to continue to develop both from the HR aspect of the information system and the development of portfolio applications that will support the continuity of business processes at PT. Serasi Autoraya (Trac) (Lah Amsal, 2019).

Research on Strategic Planning of Information Systems Using the Ward and Peppard Method at the Binterbusih Foundation in Semarang. In the research, conducted to develop a Strategic Information System plan using the Ward and Peppard approach. The approach consists of several sub-stages, namely: analyzing the internal and external environment of the business using SWOT (Strengths, Weakness, Opportunities, and Threats) while analyzing the internal and external environment of information systems and information technology using value chain, compiling application portfolio using Mc Farlan Strategic Grid. based on the results of the analysis and discussion, it is recommended the development of several information systems applications, namely: scholarship management information system, filing and asset recognition information system, financial and payroll information system, accounting information system, executive information system, website, and information system monitoring evaluation of scholarship recipients. the application is recommended to be developed in stages over a period of 4 (four) years adjusted to the organization's master plan (Wandikbo Danton, 2019).

Research on Strategic Planning of Information Systems Using the Ward and Peppard Method in the Plengkung Christian Church. The research was conducted because the growth of the Plengkung GKJ from year to year developed very rapidly, the growing congregation that was increasingly accompanied by many fields caused difficulties in the management process. Therefore, the research conducted to compile information systems strategic planning in GKJ Plengkung. The study uses the Ward and Peppard approach which consists of several sub-stages, namely; internal and external business environment analysis using PEST analysis, while internal and external environment analysis information system using SWOT and Value chain, application portfolio using Mc Farlan Strategic Grid tools. Based on the results of the research recommended several applications to be applied, namely; Congregation data processing applications, inventory information system management, GKJ Plengkung Website, Development of congregational data collection systems, Filing Systems, Financial Information Systems, Service Information Systems, Research and Development Information Systems, and Monitoring and Evaluation Systems. The Information System is recommended to be built within a period of 5 (five) years. In addition to the application, it is also recommended to improve the quality and quantity of hardware and network to support the application of information systems (Setyono, Sitokdana, and Wijaya, 2018).

Research on Strategic Planning of Information Systems / Information Technology, Lancang Kuning University Using the Ward and Peppard Method. In the research, said to answer the challenges of becoming a superior organization, it is necessary to align the process and information technology systems and business processes of the organization. Therefore, a number of things recommended in the study, namely: Roadmap for the development of the information system that is more focused on the Academic information system, Internet network restructuring, e-learning, and the quality assurance information system. This is useful in achieving the goal of excellent Lancang Kuning University 2030 (Syafitri, 2015).

\section{LITERATURE REVIEW}

In this research the problems include:

A. PT Satya Mitra Sejahtera has not implemented an adequate information system and has not implemented strategic planning so that its use is still lacking. Therefore, information systems strategic planning is needed to help improve the quality of existing business processes.

B. Limitations of this study only refer to the application of information systems strategic planning.

C. The end of the results of this study produces an application portfolio recommendation that can be implemented in 5 years ahead. 


\section{RESEARCH METHODS}

The following describes the research object, methods and stages of the research conducted;

\section{A. Information System}

Understanding the information systems according to Celinas, Oram, and Wiggins (1990) information systems are man-made systems that generally consist of a set of computer-based components and manuals that are made to collect, store and manage data and provide information output to the user.

Understanding Information Technology According to Ward and Peppard (2002) refers to the specifications of technology, especially hardware, software, and telecommunications networks that facilitate and support the process of collecting, processing, storing, dissemination, and exchanging information. According to O'Brien (2005), information technology covers the main concepts, development, and various information technology management issues namely hardware, software, networks, data management, and many internetbased technologies. So, Information Technology is a major concept related to technology that will later support a system.

\section{B. Information System Strategic Planning}

Information systems strategic planning is the process of identifying a portfolio of computer-based information system applications that will support the organization in implementing business plans and realizing its business goals. Information systems strategic planning studies the effect of information systems on business performance and contributes to the organization in choosing strategic steps. In addition, information systems strategic planning also explains various tools, techniques, and frameworks for management to align information systems strategies with business strategies, even seeking for new opportunities through the application of innovative technology (Ward and Peppard, 2002).

\section{Ward and Peppard Methodology}

Ward and Peppard version methodology approach starts from the investment condition of the information system in the past which is less useful for the organization's business goals and captures business opportunities, as well as the phenomenon of increasing an organization's competitive advantage because it is able to utilize the information system to the maximum. Insufficient investment beneficial in the information system for the organization is due to the strategic planning of the information system that is more focused on technology, not based on business needs. The Ward and Peppard methodology used in this research can be seen from Figure 1.

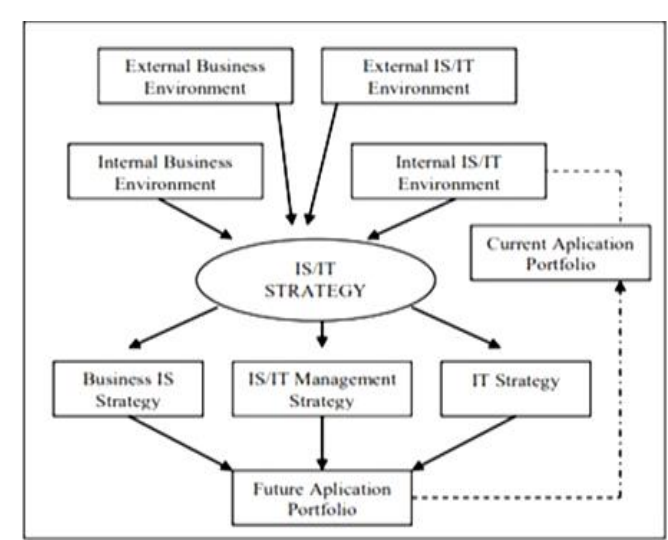

Figure 1. Strategic Model of Information System Ward \& Peppard 2002

The following are the stages of the Ward and Peppard version of the methodology. Input stages consist of:

a) Analysis of the internal business environment, which covers aspects of the current business strategy, objectives, resources, processes, and culture of the organization's business values.

b) Analysis of the external business environment, which covers aspects of the company's economic, industrial, and competitive climate.

c) Environmental analysis of the internal information system, which covers the condition of the organization's information system from the current business perspective, how it is matured, how it contributes to business, human resource skills, resources, and technology infrastructure, including how ISSP documents from the information system which exists today.

d) Environmental analysis of the external information system, which covers technological trends and opportunities for use, as well as the use of the information system by competitors, customers, and suppliers.

While the output stage is part that is carried out to produce a strategic planning document information system consisting of contents;

a) Business strategy, which covers how each business unit/function will utilize the information system to achieve its business goals, ISSP application documents, and information architecture overview.

b) Information systems strategy, which covers policies and strategies for managing information systems technology and human resources.

c) Information system management strategy, which includes general elements that are applied through the organization, to ensure the consistency of the information system policies required.

\section{Research Stages}

This study using a qualitative method. According to Sugiyono (2011), a qualitative research method is a research method based on the philosophy of postpositivism, used to examine natural conditions of objects, (as opposed to experiments) where the researcher is as a 
key instrument, the sampling of data sources is done by purposive and snowball, collection techniques with triestimation (combined), data analysis is inductive or qualitative, and qualitative research results emphasize the meaning rather than generalization.

Stage 1. At this stage, the researcher identified the problems and needs of PT Satya Mitra Sejahtera through initial observation and literature review. The identified problems form the basis for developing an Information Systems strategic planning.

Stage 2. At this stage, the authors review a variety of research that is a reference in this study, including reviewing the theoretical basis of information systems strategic planning using Ward and Peppard.

Stage 3. Data collection as for the data source in this study consists of two data sources is Primary Data and Secondary Data. Data collection in this study was carried out by the following methods:

a) Make observations for 2 weeks on the organizational activities of PT Satya Mitra Sejahtera.

b) Conduct an interview with the Director and Program Manager of PT Satya Mitra Sejahtera.

c) Documenting or reviewing documents supporting strategic planning at PT Satya Mitra Sejahtera.

Stage 4. Information System strategic planning with ward and Peppard methods:

a) Analysis of the internal and external environment of the business used PEST and Value Chain analysis tools.

b) Analysis of the information system environment using SWOT.

Stage 5. mapping the application portfolio using Mc Farlan Strategic Grid. Mapping is carried out in four categories namely: Strategic, High potential, Key operational, and support.

Stage 6. Implementation Plan, which is a description of the time period for PT Satya Mitra Sejahtera to realize the proposed information system.

Stage 7. Conclusions and Suggestions is the stage where the authors draw conclusions from the results of the analysis and discussion, then suggestions for further development are proposed.

\section{RESULTS AND DISCUSSION}

\section{A. Organization Profile}

PT. Satya Sejahtera Mitra (PT. SMS) is a company established by the Satya Wacana Christian Higher Education Foundation (YPTKSW). Previously the forerunner of this company was the SWCU Entrepreneurship Bureau. Based in Salatiga City, the company started operations on July 1, 2010. PT. Satya Mitra Sejahtera was formed by YPTKSW as an effort to realize independence as a legal entity, where almost all company ownership is controlled by YPTKSW. As a holding and parent company, PT. Satya Mitra Sejahtera manages strategic assets entrusted by YPTKSW and organizes existing business units with reference to applicable laws and good governance practices. PT. Satya
Mitra Sejahtera manages assets entrusted and can be used for business purposes. Now, PT. Satya Mitra Sejahtera has business units, namely: Subsidiary Business Units (SWCU Guest House, Shady Cafe, Car Rental, Employee Loan Unit, Souvenir Center and Uni Store) and Rental System Business Unit (Central Cafeteria, IKASATYA Foto Copy, and Tower Sign).

\section{B. External Environmental Analysis}

Analysis of the external business environment of PT. Satya Mitra Sejahtera was conducted using the PEST analysis method. PEST analysis is used to analyze the external factors that affect PT. Satya Mitra Sejahtera which concerns politics, economics, social, and technology. This analysis produces various influences of external factors that exist around the company, as follows:

$\mathrm{P}$ : Political factors that affect companies such as government policies on value-added Tax (VAT), the threat of companies not being able to develop their businesses regardless of the burden of VAT .

E : Economic factors that affect companies such as bargaining competition for lower service prices, the opportunity for companies to lease goods and services at the lowest prices compared to competing companies around.

S : Social factors that affect the company increasing population and increasing number of consumers, corporate opportunities increasing demand for goods and services and the threat that will be faced is the availability of stock of goods and services and variety of goods and services.

$\mathrm{T}$ : Technological factors that affect the company are the lifestyle trends of the surrounding community that have shifted to the gadget and internet generation, the opportunity for the company to get the promotion of media development through various types of social media.

\section{Internal Environmental Analysis}

Value Chain Analysis is an analysis conducted to map the entire business processes of PT. Satya Mitra Sejahtera which is classified as the main activity and supporting activities. The value chain analysis results can be seen from Figure 2.

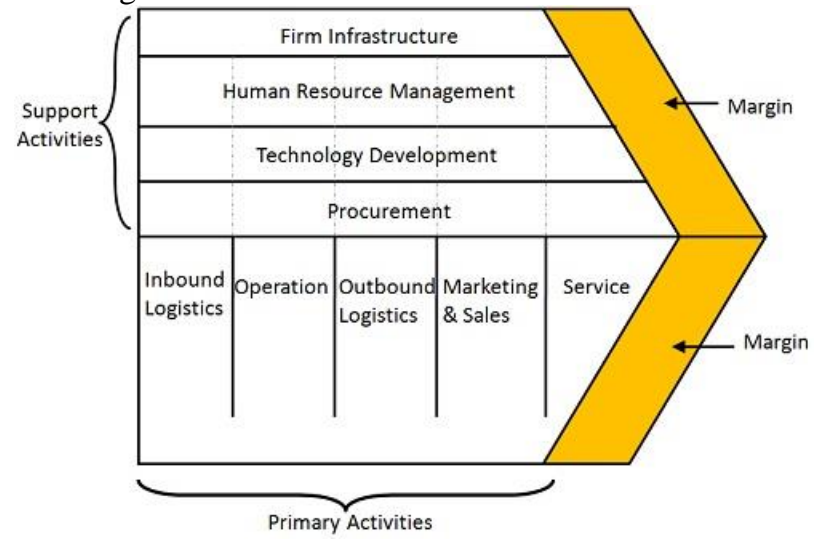

Figure 2. Value Chain Analysis Results 
Based on Figure 3, it is made as follows

A. Main Activities consist of:
a) Offering Services
b) Vehicle unit rental
c) Administration

B. Support Activities consist of:
a) Management of Human Resource
b) Management of Information System
c) Customer Service
d) Financial Management and Accounting

After knowing the main and supporting activities in PT Satya Mitra Sejahtera, it will be continued by analyzing the relationship between stakeholders and the main and supporting activities so they can find out about the activities of these stakeholders. The following table is the relationship between stakeholders and activities in PT. Satya Mitra Sejahtera can be seen in table 1.

Table 1. Relationship between Stakeholders and Organizational Activities

\begin{tabular}{|l|l|l|}
\hline \multicolumn{1}{|c|}{$\begin{array}{c}\text { Stakeholder } \\
\text { Activity }\end{array}$} & \multicolumn{1}{|c|}{$\begin{array}{c}\text { PT. Satya Mitra } \\
\text { Sejahtera }\end{array}$} & Customer \\
\hline Main Activity & $\begin{array}{l}\text { President, Manager, } \\
\text { Sales, }\end{array}$ & Customer \\
$\begin{array}{l}\text { Services } \\
\text { 2. Vehicle unit } \\
\text { rental }\end{array}$ & Administration & \\
3. Administration & & \\
\hline Support Activity & President, Manager, & Customer \\
$\begin{array}{l}\text { 1. Management of } \\
\text { Human Resource }\end{array}$ & Sales, Staff, All & \\
2. Management of & Administration & \\
Information & & \\
System & & \\
3. Customer & & \\
Service & & \\
4. Financial & & \\
Management and & & \\
Accounting & & \\
\hline
\end{tabular}

\section{Information Systems External and Internal Environment Analysis}

In analyzing external and internal information systems at PT. Satya Mitra Sejahtera performed the SWOT (Strengths, Weakness, Opportunities, and Threats) analysis technique. This analysis is based on a logic that can maximize strengths and opportunities, but at the same time can minimize weaknesses and threats in the company, so that by using this SWOT analysis can support the strategic formulation process of information systems at PT. Satya Mitra Sejahtera the Tows matrix or SWOT is used to compile strategic factors on PT. Satya Mitra Sejahtera in describing clearly how external opportunities and threats faced by the company are adjusted to the strengths and weaknesses they have in order to produce strategic in advancing the company. The following is an information system SWOT Matrix, obtained from the analysis results at PT. Satya Mitra Sejahtera can be seen from Table 2 .
Table 2. SWOT Analysis

\begin{tabular}{|c|c|c|}
\hline Internal & $\begin{array}{l}\text { STRENGTHS (S) } \\
\text { 1. Using office } \\
\text { applications } \\
\text { 2. Already have } \\
\text { a computer } \\
\text { with adequate } \\
\text { hardware } \\
\text { 3. Has a strategic } \\
\text { place } \\
\text { The computer } \\
\text { already has an } \\
\text { internet } \\
\text { network }\end{array}$ & $\begin{array}{l}\text { WEAKNESSES }(\boldsymbol{W}) \\
\text { 1. There are no } \\
\text { experienced human } \\
\text { resources in the } \\
\text { field of information } \\
\text { systems } \\
\text { 2. Not yet able to } \\
\text { handle if there is } \\
\text { trouble } \\
\text { 3. The absence of a } \\
\text { website } \\
\text { 4. There is no } \\
\text { database for } \\
\text { employee data }\end{array}$ \\
\hline $\begin{array}{l}\text { OPPORTUNITIES } \\
\text { (O) } \\
\text { 1. The training for } \\
\text { management of } \\
\text { information } \\
\text { systems } \\
\text { 2. The existence } \\
\text { of human } \\
\text { resources in the } \\
\text { field of } \\
\text { professional } \\
\text { information } \\
\text { systems }\end{array}$ & $\begin{array}{l}\text { STRATEGY SO } \\
\text { (STRENGTHS- } \\
\text { OPPORTUNITIES) } \\
\text { 1. Human resources } \\
\text { in the field of } \\
\text { professional } \\
\text { information } \\
\text { systems and can } \\
\text { maximize } \\
\text { computers that } \\
\text { already have } \\
\text { internet networks } \\
\text { 2. The existence of an } \\
\text { adequate computer } \\
\text { can facilitate the } \\
\text { training process }\end{array}$ & $\begin{array}{l}\text { STRATEGY WO } \\
\text { (WEAKNESSES- } \\
\text { OPPORTUNITIES) } \\
\text { 1. Conduct training for } \\
\text { inexperienced } \\
\text { human resources in } \\
\text { the field of } \\
\text { information systems } \\
\text { 2. Recruiting human } \\
\text { resources in the } \\
\text { field of } \\
\text { professional } \\
\text { information } \\
\text { systems to handle } \\
\text { the trouble } \\
\text { 3. Recruiting human } \\
\text { resources in the field } \\
\text { of information } \\
\text { systems to create } \\
\text { and manage } \\
\text { websites } \\
\text { 4. Develop an } \\
\text { employee database } \\
\text { information system }\end{array}$ \\
\hline $\begin{array}{l}\text { TREATHS }(\mathrm{T}) \\
\text { 1. Many } \\
\text { competitors } \\
\text { with similar } \\
\text { businesses } \\
\text { 2. Rapid } \\
\text { technological } \\
\text { development }\end{array}$ & $\begin{array}{l}\text { STRATEGY ST } \\
\text { (STRENGTHS- } \\
\text { THREATS) } \\
\text { 1. Improve the } \\
\quad \text { quality of } \\
\text { promotions with } \\
\text { the internet } \\
\text { 2. Can add } \\
\text { information } \\
\text { systems } \\
\text { applications with } \\
\text { adequate } \\
\text { computers }\end{array}$ & $\begin{array}{l}\text { STRATEGY SO } \\
\text { (STRENGTHS- } \\
\text { THREATS) } \\
\text { 1. Increase the } \\
\text { capacity of the } \\
\text { information system } \\
\text { workforce } \\
\text { 2. Establish } \\
\text { relationships with } \\
\text { companies to find } \\
\text { out technological } \\
\text { developments }\end{array}$ \\
\hline
\end{tabular}

\section{E. Application Portfolio (Mc Farlan Strategic Grid)}

Based on the results of the information system strategy and business strategy, a portfolio application with priority and strategic information system blueprint that guided by Mc Farlan Strategic Grid. The method is used to map the information system application based on its contribution to the organization. Mapping is done in four quadrants (strategic, high potential, key operations, and support). From the mapping results obtained an overview of the 
contribution of an information system application to the organization and development in the future.

Table 3. Application Portfolio

\begin{tabular}{|ll|l|}
\hline \multicolumn{1}{|c|}{ Strategic } & \multicolumn{1}{c|}{ High Potential } \\
\hline$>\quad$ Company Website & $>\quad \begin{array}{l}\text { Financial information } \\
\text { systems }\end{array}$ \\
\hline$>\quad \begin{array}{l}\text { Guest reservation } \\
\text { information system } \\
\begin{array}{l}\text { Filing Information } \\
\text { Systems and reports } \\
\text { Payroll information system }\end{array}\end{array}$ & $\begin{array}{l}\text { Employee Database } \\
\text { Information System }\end{array}$ \\
\hline Key Operational & Support \\
\hline
\end{tabular}

Description of table 3:

- $\quad$ Strategic is a very wide range of applications in the organization.

- Key Operational is applications that are currently the success of the organization.

- High Potential is applications that have the potential to improve the organization in the future.

- $\quad$ Support is a very valuable application but does not make the success of the organization dependent

Based on the results of interviews and observations found that PT. Satya Mitra Sejahtera does not yet have an information system application, researchers propose several Information system applications as needed at PT. Satya Mitra Sejahtera that have been mentioned in the table above. The proposed application is determined in the development priority map using the Mc Farlan Strategic Grid which consists of 4 categories. Based on the mapping in Table 1, the application development priorities are recommended, as follows: The first stage is key operational because these applications are the key to the success of PT. Satya Mitra Sejahtera. The second stage is strategic because these applications are very influential in the ongoing business processes in PT. Satya Mitra Sejahtera. The third stage is Support because with the support of applications can help every business process at PT. Satya Mitra Sejahtera. The Fourth Stage is High Potential because these applications determine the development of PT. Satya Mitra Sejahtera was upcoming

\section{F. Implementation Planning}

Information System development or implementation plans adjusted to the order of application development priorities that have been mapped in the Mc Farlan Strategic Grid application portfolio. A number of these applications will be developed gradually over 5 (years) adapted to the organization's master plan, which can be seen from table 4.
Table 4. Implementation planning of information systems at PT. Satya Mitra Sejahtera

\begin{tabular}{|l|c|c|c|c|c|}
\hline \multicolumn{1}{|c|}{ Recommendation } & \multicolumn{5}{c|}{ Year } \\
\cline { 2 - 6 } & 1 & 2 & 3 & 4 & 5 \\
\hline $\begin{array}{l}\text { Filing Information System and } \\
\text { reports }\end{array}$ & $\mathrm{V}$ & & & & \\
\hline Payroll Information System & & $\mathrm{V}$ & & & \\
\hline $\begin{array}{l}\text { Guest reservation information } \\
\text { system }\end{array}$ & & $\mathrm{V}$ & & & \\
\hline Financial Information System & & & $\mathrm{V}$ & & \\
\hline $\begin{array}{l}\text { Company Website } \\
\text { Employee database Information } \\
\text { System }\end{array}$ & & & & $\mathrm{V}$ & \\
\hline
\end{tabular}

\section{CONCLUSION}

From the results of the analysis conducted on various data obtained using the Ward and Peppard method, it can be concluded that the Strategic Planning of Information Systems at PT. Satya Mitra Sejahtera can be used as a tool to maximize the performance of the information system in achieving the goals of the company's business processes, so it can be concluded that strategic design research using Ward and Peppard methods can produce maps of internal and external conditions of the organization, so as to know the strengths, weaknesses, opportunities and the threat posed by PT. Satya Mitra Sejahtera, besides that, can also find out every major activity or support whether the vision and mission are going well, can be explained using the value chain, and also the results of information system strategic planning in the form of application proposals that will be implemented within the timeframe set at PT. Satya Mitra Sejahtera in accordance with the needs of the company so that it can provide benefits for the continuity of the company's business processes.

\section{REFERENCES}

Amsal, Rahardja, Sitokdana, 2019. Perencanaan Strategis Sistem Informasi Menggunakan Ward and Peppard (Studi kasus : PT serasi Autoraya). Repository Universitas Kristen Satya Wacana Salatiga. Setyono, Sitokdana, Wijaya, 2018. Perencanaan Strategis Sistem Informasi Menggunakan Ward and Peppard (Studi kasus : Gereja Kristen Jawa Plengkung). Repository Universitas Kristen Satya Wacana Salatiga.

Sugiyono. 2011. Metode Penelitian Kuantitatif, Kualitatif dan R\&D. Bandung: Afabeta.

Syafitri, W. 2015. "Perencanaan Strategi Sistem Informasi / Teknologi Informasi Universitas Lancang Kuning," Jurnal Teknologi Informasi \& Komunikasi Digital Zone, 7(1), hal. 31-43. doi: https://doi.org/10.31849/digitalzone.v7i1.523.

O’Brien, James A. 2005. Pengantar Sistem Informasi Akuntansi: Perspektif Bisnis dan Manajerial.

Wandikbo, Sitokdana, 2019. Perencanaan Strategis Sistem Informasi Menggunakan Ward and Peppard (Studi kasus: PT serasi Autoraya). Repository Universitas Kristen Satya Wacana Salatiga.

Ward, J., Peppard, J., 2002, Strategic Planning for Information Systems. 3rd Ed., UK: John Wiley \& Sons, Ltd. 